\title{
Gene-environment interaction: The causes of high obesity incidence
}

\author{
Mohammed S. Ellulu ${ }^{1,2 *}$ and Marwan O. Jalambo ${ }^{2}$ \\ ${ }^{1}$ Clinical Nutrition Specialist, Gaza, Palestine \\ ${ }^{2}$ Faculty of Pharmacy, Al-Azhar University of Gaza (AUG), Palestine
}

\begin{abstract}
Urbanization has provided experimental settings for testing the interactive relationship between genetic background and changes in lifestyle and dietary patterns. The concept of gene-environment interaction was described by epidemic of obesity along with urbanization. Genome-wide association has identified several genes such as melanocortin-4 receptor that associates with environmental influences of obesity. Gene environment (GxE) interaction refers to modification by an environmental factor of the effect of a genetic variant on a phenotypic trait. GxE interactions can serve to modulate the adverse effects of a risk allele, or can exacerbate the genotypephenotype relationship and increase risk.
\end{abstract}

\section{Review}

The recent epidemic of obesity along with the increasing spread of Western-type lifestyles worldwide is a good illustration of the concept of gene-environment interaction. Because the gene pool of a certain population has been relatively constant for many generations, it seems that dramatic changes in lifestyle and dietary habits have played a role in triggering the recent surge of excessive adiposity [1].

Urbanization and migration have provided good experimental settings for testing the interactive relationship between genetic background and changes in lifestyle and dietary patterns. Risk of obesity increases after migration from poor to affluent countries [2]; the adoption of a Western dietary pattern is believed to be the major cause of the obesity prevalent in immigrants [3]. In the United States, Asian American and Hispanic American adolescents are more than twice as likely to be obese as first-generation immigrants from their countries of origin [4].

Obesity is a multifactorial abnormality that has a genetic basis but requires environmental influences to manifest. Several genes such as FTO (fat mass and obesity associated) and MC4R (melanocortin-4 receptor) identified by genome-wide association (GWA) scans have been convincingly associated with obesity risk in various populations $[5,6]$.

A gene environment ( $\mathrm{GxE}$ ) interaction refers to modification by an environmental factor of the effect of a genetic variant on a phenotypic trait [7]. Environmental factors can include climate, diet, dietary components such as saturated fatty acids, physical activity, sedentary behavior, alcohol, or sleep, among many others. Such GxE interactions can serve to modulate the adverse effects of a risk allele, or can exacerbate the genotype-phenotype relationship and increase risk [8].

Gene-environment (GxE) interactions describe a modifiable relationship between genetic variation and changes in phenotype $[9,10]$. To accomplish homeostasis, adjustments to molecular parameters must be enacted that correspond to the stimulatory challenge, which typically includes altered protein function or gene expression. This all amounts to continual changes to the phenotypes of the cell or organism and it is the timeliness and efficiency of these phenotypic adjustments that determine health and healthy aging. This process can be termed phenotypic flexibility, a phenomenon which is a central concept of the gene-environment interaction [11].

A report in 2011 cataloged $554 \mathrm{GxE}$ interactions, 377 of which contained common traits and environmental factors, that reached statistical significance and were pertinent to nutrition, cardiovascular diseases, blood lipids and type- 2 diabetes mined from 184 scientific reports [12]. Table (1) describes selected observational studies of genelifestyle interactions on obesity:

\begin{tabular}{|c|c|c|c|}
\hline Reference & $\begin{array}{c}\text { Gene } \\
\text { (Variants) }\end{array}$ & $\begin{array}{c}\text { Lifestyle } \\
\text { factors }\end{array}$ & \multicolumn{1}{|c|}{ Major findings } \\
\hline $\begin{array}{c}\text { Alonso, } \text { et al. } \\
{[13]}\end{array}$ & $\begin{array}{c}\text { UCP3 } \\
(-55 \mathrm{C}>\mathrm{T})\end{array}$ & $\begin{array}{c}\text { Physical } \\
\text { activity }\end{array}$ & $\begin{array}{l}\text { Carrying T-allele was } \\
\text { associated with lower } \\
\text { risk of obesity only } \\
\text { in those with higher } \\
\text { physical activity. }\end{array}$ \\
\hline $\begin{array}{c}\text { Ridderstrale, } \\
\text { et al. }[14]\end{array}$ & $\begin{array}{c}\text { PPARGC1A } \\
\text { (GLy482Ser })\end{array}$ & $\begin{array}{c}\text { Physical } \\
\text { activity }\end{array}$ & $\begin{array}{l}\text { Elderly men carrying } \\
\text { Ser-allele had increased } \\
\text { risk of obesity }\end{array}$ \\
\hline $\begin{array}{c}\text { Miyaki, } \text { et al. } \\
{[15]}\end{array}$ & $\begin{array}{c}\text { ADRB3 } \\
\text { (Trp64Arg) }\end{array}$ & Total energy & $\begin{array}{l}\text { Arg64-allele carriers } \\
\text { were associated with } \\
\text { greater obesity risk than } \\
\text { Trp64Trp homozygotes, } \\
\text { but only in the highest } \\
\text { energy intake quartile. }\end{array}$ \\
\hline & & & \\
\hline
\end{tabular}

Correspondence to: Mohammed S. Ellulu, Clinical Nutrition Specialist; Faculty of Pharmacy, Al-Azhar University of Gaza (AUG), Palestine, Tel: +970-599784862, E-mail: mohdsubhilulu@gmail.com

Key words: obesity, gene-environment interaction, environmental factors, genetic predisposition, social networks

Received: May 20, 2017; Accepted: June 09, 2017; Published: June 12, 2017 


\begin{tabular}{|c|c|c|c|}
\hline $\begin{array}{l}\text { Song, et al. } \\
\text { [16] }\end{array}$ & $\begin{array}{c}\text { IL6R } \\
\text { (Asp358Ala) }\end{array}$ & Total energy & $\begin{array}{l}\text { Energy intake was } \\
\text { significantly associated } \\
\text { with WC in T-allele } \\
\text { carriers, but not in } \\
\text { GG homozygotes } \\
\text { (p-interaction=0.03). }\end{array}$ \\
\hline $\begin{array}{c}\text { Marti, et al. } \\
\text { [17] }\end{array}$ & $\begin{array}{c}\text { PPARG } \\
\text { (Pro12Ala) }\end{array}$ & Carbohydrate & $\begin{array}{l}\text { Pro12Ala was associated } \\
\text { with increased risk of } \\
\text { obesity only in those } \\
\text { with higher CHO intake } \\
\text { (p-interaction=0.02). }\end{array}$ \\
\hline $\begin{array}{c}\text { Martinez, et } \\
\text { al. }[18]\end{array}$ & $\begin{array}{c}\text { ADRB2 } \\
\text { (Gln27Glu) }\end{array}$ & Carbohydrate & $\begin{array}{l}\text { Women with high } \mathrm{CHO} \\
\text { intake had greater risk } \\
\text { of obesity than those } \\
\text { with low CHO intake } \\
\text { only in Gln } 27 \mathrm{Glu} \\
\text { heterozygotes. }\end{array}$ \\
\hline $\begin{array}{c}\text { Nieters, et al. } \\
\text { [19] }\end{array}$ & $\begin{array}{l}11 \text { genes } \\
\text { (15 SNPs) }\end{array}$ & n-6 PUFAs & $\begin{array}{l}\text { Substantial interaction } \\
\text { between variants in } \\
\text { PPARG2, TNFA, leptin } \\
\text { (possibly APM1, HSL) } \\
\text { and dietary n-6 FA } \\
\text { intake in relation to } \\
\text { obesity risk. }\end{array}$ \\
\hline $\begin{array}{c}\text { Robitaille, et } \\
\text { al. }[20]\end{array}$ & $\begin{array}{c}\text { PPARG } \\
\text { (Pro12Ala) }\end{array}$ & $\begin{array}{c}\text { Total fat, } \\
\text { Saturated FAs }\end{array}$ & $\begin{array}{l}\text { In women, Pro12Pro } \\
\text { homozygotes were } \\
\text { positively associated } \\
\text { with total fat and SFA } \\
\text { intake in relation to WC } \\
\text { and BMI, but not in } \\
\text { Ala-allele carriers. }\end{array}$ \\
\hline
\end{tabular}

According to Ellulu [21], obesity is caused by a complex interaction between the environment, genetic predisposition, and human behavior as the following:

1- Environmental factors are likely to be major contributors to the obesity epidemic. It is certain that obesity develops when there is a positive imbalance between energy intake and energy expenditure. Evidence supports the contribution of both excess energy intake and decreased energy expenditure in the obesity epidemic:

(1) Kant and Graubard [22] mentioned that the temporal trends in the increase of the quantity and energy density of foods consumed by adults parallel the increasing prevalence of obesity in the U.S. population. (2) Dietz and Gortmaker [23] demonstrated that the prevalence of obesity increased by $2 \%$ for each additional hour of television viewed. (3) There is also evidence that the relative availability and price of different food products affect food consumption [27]. (4) The built environment, such as quality of local parks, affects the level of physical activities in a community [25].

2- In addition to environmental factors, there is genetic predisposition to obesity. The single gene mutations are responsible for rare forms of monogenic obesity (leptin [LEP], leptin receptor [LEPR], melanocortin-4 receptor [MC4R], and pro-opiomelanocortin [POMC]) [26].

However, there is growing evidence that common genetic variants or single-nucleotide polymorphisms (SNP) may play an important role in the obesity epidemic. These SNPs have modest effects on an individual susceptibility to common forms of obesity, but due to their high frequency, they can have a large contribution to obesity on the population level [27]. Frayling, et al. [6] used a genome-wide association (GWA) study to identify a SNP located in the fat mass and an obesity-associated gene (FTO) that is associated with an increased risk of common obesity. FTO was initially identified in a GWA study to be associated with an increased risk of type 2 diabetes mediated through an effect BMI. In a GWA study of 38,759 patients, Frayling, et al. [6] found that a person who is homozygous for the risk allele (rs9939609 A allele) had a 1.67-fold increased odds of obesity when compared with those who do not have the risk allele.

3- Social networks have an important role in the obesity epidemic. Christakis and Fowler [28] explored the hypothesis that obesity may spread through social networks by evaluating an interconnected social network of more than 12,000 people from the Framingham Heart Study to examine the effects of weight gain among friends, siblings, and spouses. They found that a person's risk of becoming obese increased by $57 \%$ if a friend became obese, the risk of becoming obese increased by $40 \%$ and $37 \%$ if a person had a sibling or spouse who became obese, respectively.

\section{Conflicts of interest}

The authors declare that there is no conflict of interest regarding the current presentation.

\section{References}

1. Qi L, Cho YA (2008) Gene-environment interaction and obesity. Nutr Rev 66: 684-694 [crossref]

2. Kaplan MS, Huguet N, Newsom JT, McFarland BH (2004) The association between length of residence and obesity among Hispanic immigrants. Am J Prev Med 27: 323326. [crossref]

3. Ferreira SR, Lerario DD, Gimeno SG, Sanudo A, Franco LJ; Japanese-Brazilian Diabetes Study Group (2002) Obesity and central adiposity in Japanese immigrants: role of the Western dietary pattern. J Epidemiol12: 431-438.[crossref]

4. Popkin BM (1998) The nutrition transition and its health implications in lower-income countries. Public Health Nutr1: 5-21.[crossref]

5. Loos RJ, Lindgren CM, Li S, Wheeler E, Zhao JH, et al. (2008) Common variants near MC4R are associated with fat mass, weight and risk of obesity. Nat Genet 40: 768-775. [crossref]

6. Frayling TM, Timpson NJ, Weedon MN, Zeggini E, Freathy RM, et al. (2007) A common variant in the FTO gene is associated with body mass index and predisposes to childhood and adult obesity. Science 316: 889-894.[crossref]

7. Ordovas JM (2008) Genotype-phenotype associations: modulation by diet and obesity. Obesity (Silver Spring)16 Suppl 3: S40-46.[crossref]

8. Parnell LD, Lee YC, Lai CQ (2010) Adaptive genetic variation and heart disease risk. CurrOpinLipidol21: 116-122.[crossref]

9. Andreassi MG (2009) Metabolic syndrome, diabetes and atherosclerosis: influence of gene-environment interaction. Mutat Res 667: 35-43.[crossref]

10. Zheng JS, Arnett DK, Lee YC, Shen J, Parnell LD, et al. (2013) Genome-wide contribution of genotype by environment interaction to variation of diabetes-related traits. PLoS One 8: e77442.[crossref]

11. van Ommen B, van der Greef J, Ordovas JM, Daniel H (2014) Phenotypic flexibility as key factor in the human nutrition and health relationship. Genes Nutr 9 : 423.[crossref]

12. Lee YC, Lai CQ, Ordovas JM, Parnell LD (2011) A database of gene-environment interactions pertaining to blood lipid traits, cardiovascular disease and type 2 diabetes. J Data Mining Genomics Proteomics2:106.[crossref]

13. Alonso A, Martí A, Corbalán MS, Martínez-González MA, Forga L, et al. (2005) Association of UCP3 gene -55C $>\mathrm{T}$ polymorphism and obesity in a Spanish population. Ann NutrMetab49: 183-188.[crossref]

14. Ridderstråle M, Johansson LE, Rastam L, Lindblad U (2006) Increased risk of obesity associated with the variant allele of the PPARGC1A Gly482Ser polymorphism in physically inactive elderly men. Diabetologia49: 496-500. [crossref] 
15. Miyaki K, Sutani S, Kikuchi H, Takei I, Murata M, et al. (2005) Increased risk of obesity resulting from the interaction between high energy intake and the Trp64Arg polymorphism of the beta3-adrenergic receptor gene in healthy Japanese men. $J$ Epidemiol15: 203-210.[crossref]

16. Song Y, Miyaki K, Araki J, Zhang L, Omae K, et al. (2007) The interaction between the interleukin 6 receptor gene genotype and dietary energy intake on abdominal obesity in Japanese men. Metabolism 56: 925-930.[crossref]

17. Marti A, Corbalán MS, Martínez-González MA, Forga L, Martínez JA (2002) CHO intake alters obesity risk associated with Pro12Ala polymorphism of PPARgamma gene. J PhysiolBiochem58: 219-220.[crossref]

18. Martínez JA, Corbalán MS, Sánchez-Villegas A, Forga L, Marti A, et al. (2003) Obesity risk is associated with carbohydrate intake in women carrying the Gln27Glu beta2-adrenoceptor polymorphism. J Nutr133: 2549-2554.[crossref]

19. Nieters A, Becker N, Linseisen J (2002) Polymorphisms in candidate obesity genes and their interaction with dietary intake of $\mathrm{n}-6$ polyunsaturated fatty acids affect obesity risk in a subsample of the EPIC-Heidelberg cohort. Eur J Nutr41: 210-221. [crossref]

20. Robitaille J, Després JP, Pérusse L, Vohl MC (2003) The PPAR-gamma P12A polymorphism modulates the relationship between dietary fat intake and components of the metabolic syndrome: results from the Quebec Family Study. Clin Genet63: 109116. [crossref]
21. Ellulu MS (2017) Obesity, cardiovascular disease, and role of vitamin C on inflammation: a review of facts and underlying mechanisms.Inflammopharmacology25: 313-328. [crossref]

22. Kant AK, Graubard BI (2006) Secular trends in patterns of self-reported food consumption of adult Americans: NHANES 1971-1975 to NHANES 1999-2002. Am J ClinNutr84: 1215-1223.[crossref]

23. Dietz WH Jr, Gortmaker SL (1985) Do we fatten our children at the television set? Obesity and television viewing in children and adolescents. Pediatrics75: 807-812. [crossref]

24. Holsten JE (2008) Obesity and the community food environment: a systematic review. Public Health Nutr 12: 397-405. [crossref]

25. Kipke MD, Iverson E, Moore D, Booker C, Ruelas V, et al. (2007) Food and park environments: neighborhood-level risks for childhood obesity in east Los Angeles. Adolesc Health40: 325-333. [crossref]

26. Andreasen CH, Andersen G (2009) Gene-environment interactions and obesity--further aspects of genomewide association studies. Nutrition 25: 998-1003.[crossref]

27. Tiret L, Poirier O, Nicaud V, Barbaux S, Herrmann SM, et al. (2002) Heterogeneity of linkage disequilibrium in human genes has implications for association studies of common diseases. Hum Mol Genet 15: 419-429.[crossref]

28. Christakis NA, Fowler JH (2007) The spread of obesity in a large social network over 32 years. $N$ Engl J Med357: 370-379. [crossref]

Copyright: $\odot 2017$ Ellulu MS. This is an open-access article distributed under the terms of the Creative Commons Attribution License, which permits unrestricted use, distribution, and reproduction in any medium, provided the original author and source are credited. 